\title{
Ideological And Historical Challenges In Business Education
}

\author{
Lana Nino, Whittier College, USA
}

\begin{abstract}
Business schools bear a central mission in our society and are responsible for training business managers who work in, lead, and indeed control our corporations and drive our economy's wealth. Historical and ideological challenges have influenced business education and steered it off the expected path. Several theoretical frameworks such as academic capitalism explain what has occurred in this profession and how academic institutions were held hostage to the capitalistic and entrepreneurial organizations that are more concerned with shareholders' wealth than stakeholders' wellbeing and welfare.
\end{abstract}

Keywords: Academic capitalism; agency; business education; challenges in business education; institutional isomorphism; professionalism; resource dependency

\section{INTRODUCTION}

n the extant literature, various scholars enumerated the problems that weigh upon business education,
economically, ideologically and technologically (Crainer \& Dearlove, 1999; Daniel, 1998; Drucker,
1968; Epstein, 2006; Friga, Bettis, \& Sullivan, 2003; Gregg \& Stoner, 2008; Hawawini, 2005; Hugstad, 1983; Khurana, 2007; Mårtensson, Bild, \& Nilsson, 2008; Pearce, 1999; Porter \& McKibbon, 1988). Some of the challenges have been historical, dating back to the early 20th century when business schools started to form under the influence of market forces (Gordon \& Howell, 1959; Pierson, 1959; Porter \& McKibbon, 1988)); other challenges have resulted from the growth of the business enterprise in the last century which has lead to the proliferation of programs in business education (Benson, 2004; Crainer \& Dearlove, 1999). In an attempt to uncover the ways business education has developed, theoretical educational perspectives will be connected to the challenges observed in the field, analyzed and summarized, ultimately leading to recommendations on how these challenges can be addressed.

\section{THEORETICAL FRAMEWORK}

The following section introduces theories that provide explanatory value to the challenges facing business education. The theories below provide a useful framework that will assist in understanding the evolution of the field. The selected theories are not the only applicable ones to the review but have been chosen due to their close interconnectedness to the problems presented.

\section{Academic Capitalism}

Colleges and Universities emerged as non-profit organizations that are heavily dependent on state and federal funding. Academic organizations had high aims and aspirations for their institutional missions. As time passed and federal and state funding decreased, these institutions and programs within it such as business education programs had to reinvent themselves and depend more heavily on other sources of funding such as private and industry funds. The construct of this as noted by Slaughter and Rhoades (1997) in their Academic Capitalism Theory is based on the premise that administrators of educational institutions have slowly separated their enterprises from state and federal government and have become closer and more connected to the market. Knowledge has become a commodity that can be extracted, manufactured, and sold as a private good, and the original aim of making knowledge available to all has been thwarted by market mechanisms. This theory has surely influenced educational offerings in business programs, where the field has enjoyed even a stronger connection to the market 
than other disciplines (Behrman \& Levin, 1984; Epstein, 2006; French \& Grey, 1996). Business programs have traditionally developed curriculum in response to the needs of the market place and emphasized students' skills that have high demand in industry and relinquished the professional training that was one of the primary goals for including business training at the university level (Khurana, 2007; Pierson, 1959).

\section{Institutional Isomorphism}

The theory of institutional isomorphism posits that organizations model other organizations in form and in structure not based on the best model available but on the premise of the most legitimate model. Moreover, the replication often occurs due to formal or informal pressure applied on the joining organization. Powell and DiMaggio (1991) established three types institutional structures: 1) coercive isomorphism 2) mimetic isomorphism 3) normative isomorphism, a type that is associated with professionalization. This third type helps explain the normative rules accepted by the different professions e.g. medicine, law, business that help organize the participants within it. Universities and colleges are enablers of professional isomorphism since they help establish the organizational norms and the formal education that exists within each profession. These institutions are good examples of organizations that have been created through isomorphism. Business education programs within the colleges are also a good example of this theory; many of these programs were created based on replication and not based on the "best" model copied (Khurana, 2007). Thus, during the proliferation of business education programs, the curriculum and courses used were founded based on prior models that spread very quickly and without intentional gradual improvements to the legitimate model in place.

\section{Agency}

Business managers are not the owners of the company; they are in the position of an agent for the organization in charge of directing the operations for the firm. Since human-beings are afflicted with self-interest, it is difficult to assume that managers will prioritize the interests of the company ahead of their own. Jensen (1996) theorizes that although managers' intentions are compromised by their self-interest and personal agenda, they are still able to operate semi- efficiently since they are motivated to minimize conflicts which Jensen (1996) defines as "agency costs." Agency costs, or the minimization of conflict concept, apply to the manager's desire to perform in their jobs and be loyal to the shareholders, in order for the managers to keep their positions and advance in their careers. This theory is applicable to business managers in a capitalistic society where the corporate structure separates the owners (shareholders) from the managers. The managers become the shareholders' agents running the operations of the corporation. Educational institutions are responsible for training these business managers. A manager's training implicitly includes professional training that imposes responsibility on these managers' not only to behave ethically toward their shareholders but society in general. The training of these agents/managers is the responsibility of business schools (Khurana, 2007; Mintzberg, 2004; Swanson \& Frederick, 2003), and therefore business programs that are lacking in professional content can create problems for the shareholders of corporations and society who rely on business schools for that training.

\section{Professionalism}

The Professionalism Theory borrows from Institutional Theory in that it uses organized constructs to classify expertise. Knowledge requires an extensive amount of learning and human decision making to manage the knowledge. The promise of a profession in terms of prestige, compensation, and social network is a desired goal for individuals (Abbott, 1988; Brint, 1996). The preceding theory was posited by Andrew Abbott (1988). These professions form organized bureaucracies in areas such as law, medicine, accounting, engineering and architecture. Colleges and universities have been the dominant mechanisms for producing professionals. Additionally, professional organizations perform as a fabric holding professionals together once they graduate from college based on institutionalized arrangements that create economic returns to their constituencies (Abbott, 1988). Moreover, professional organizations form a code of ethics that all the participants follow and respect. Krause (1999) argues that professional organizations are losing control over their professionals, and that control is increasingly being shifted to the state and the capitalists utilizing the professionals. This theory can assist in explaining the influence the market has over the professionals that may affect the professional bond and code of ethics that these groups adhere to. 


\section{Resource Dependency}

Pfeffer and Salancik (2003) posit that organizations are connected to other entities within their environment; none of which can work autonomously or solely self directed. Organizations depend on resources to function and survive. The limitation of resources imposes a power structure on the participants within the environment that shifts power according to the participants with the most resources. Organizations that lack the resources must cooperate with the ones that have resources. Colleges and universities and the programs within them (e.g. business programs) lack the financial resources that can allow them to run autonomously; therefore they must depend on outside funding sources, such as corporations and private sources to help with their operating expenses. This resource dependency can result in unintended consequences to the goals and missions of the educational institution and the programs within it (Pfeffer \& Salancik, 2003).

\section{CHALLENGES FACING BUSINESS EDUCATION}

The following sections review the literature written on business education, business schools, and the problems arising from historical, ideological, institutional and economic perspectives influencing the field. Understanding this background will help illuminate the reasons for the issues experienced in the discipline, as well as obstacles that stand in the way of making improvements. This analysis will result in a theoretical foundation that will assist in making recommendations for improvements in the final section of this paper.

\section{Historical Influences}

Since the inception of business education in the early part of the $20^{\text {th }}$ century, the discipline was shaped by the forces of the market place. Business education was not created based on research and scientific methods, but it evolved based on industry procedures and practices that were later compiled into business theory and textbooks (Pierson, 1959). In the post world war II era, there was strong demand for business graduates driven by the business expansion that occurred, which intensified the need for business managers. Pierson (1959) found that the most acute problem in business education was the lack of strong academic standards and professional training needed to produce scholarly graduates at the four-year college level. One of the earliest mentions of business schools defined as professional schools was found in the University of Oregon course catalogue of 1900-1901. The catalogue stated that occupations in the management of civil and consular service, banking, transportation, and domestic and foreign commerce were rapidly approximating the character of a profession which had scientific training equating to learned professions such as law and medicine (Daniel, 1998).

However, language equating business with the professions has signified more than the scientific function of professional management. When Charles Elliot, president of Harvard University, from 1869 to 1909 used the term of "profession" with his Puritan predecessors, he explicitly applied a sacred meaning which invoked the notion of a calling in which the ethical dimension was just as important as the exercise of expert knowledge (Khurana, 2007). Consequently, Edwin F. Gay, an economic historian at Harvard Business School (HBS) saw another dimension that is vital to professionalism in business: the placement of the study of business on a firm intellectual footing, which would associate business as a profession with the social implications and heightened sense of responsibility similar to other professions (Cruikshank, 1987). Gay's defense of HBS's mission of professionalizing management extended beyond knowledge and competence transcending the mere concept of profit-making (Khurana, 2007). So when universities decided to bring business schools on campus and include them as part of higher education in the early $20^{\text {th }}$ century, these universities pledged that the business discipline would be extended beyond expert knowledge to encompass the promise of professionalism.

It was after the Gordon and Howell report and Pierson's study that the American Assembly of Collegiate Schools of Business (AACSB) developed curricular standards for the field requiring students to take up to $60 \%$ of their course-work in the liberal arts area (Mason, 1990). The AACSB mandate characterized a movement away from vocationalism toward the liberal arts foundation for business graduates. The challenges then were that the business field was new, and the daily aspects of business careers had remote connections to academic work that was taught at the college level. But the need for graduates was high, and enrollment in business school was burgeoning, which decreased the incentive for business schools to enforce standards of professional training within business 
curriculum when the industry was not demanding them. Thus, much of the improvements in business education veered in the direction of expert knowledge in the functional areas such as marketing, finance, and accounting rather than the professional training intended since the inception of college-level business schools.

\section{Ideological Influences}

Perhaps the most significant influence on the market and on business schools in the $20^{\text {th }}$ century is the creation of the profession of the "business managers." Jensen's (1996) agency theory explains that the business manager, who is neither an owner nor a shareholder of the company, but merely an agent of the company, will behave in his or her own self-interest rather than that of the company or its shareholders. Yet, at the same time, the business manager is motivated to minimize conflict with shareholders and external actors, for the benefits managers receive from their jobs. Jensen calls this phenomenon "agency costs." Khurana (1997) explained that the agency theory was used extensively to explain the role of managerialism and its legitimacy in a capitalist society. One of the reasons that the business schools were founded was to create professional entities and organizations responsible for training the business manager. This training involved socializing the business manager into a culture of professionalism, as theorized by Abbott (1988), thereby legitimizing managerial authority in society. Khurana (1997) explained the original mission of business schools as follows:

The profit-maximizing imperatives of business were seen to be at odds with the more disinterested mission of universities. Business education came to be an accepted and uncontroversial part of the university only through the efforts of a vanguard of institutional entrepreneurs, both academics and managers, who saw the need for creating a managerial class that would run America's large corporations in a way that served the broader interests of society rather than the narrowly defined ones of capital or labor. p. 4

With this mission, business schools carried a pivotal societal role in training business managers. The business manager, trained within the professional guidelines of business schools, was entrusted with the management of America's corporations. Therefore, when economic downfalls occurred and business scandals escalated, the business manager profession and the training provided by the business schools were to blame (Khurana, 1997). This ethical challenge as it relates to the training of business managers provides an excellent opportunity for further research in the area of business education.

\section{Inherent Discipline Issues}

The market demands a variety of skills from business graduates, thus the training of business graduates had to become specialized. With the broadening business discipline in sub-functional areas such as marketing, accounting, finance, and management, it is difficult to balance the appropriate training for the mentioned areas. In many cases, business programs opted to teach what was offered by other schools rather than originate new programs in the various sub-areas. Mason (1990) reported that critics of the business schools in the 1980s have been frustrated with the drastic increase in the number of the schools and the slowness in adapting a new curriculum for the new global economy. This can be illuminated using Powell and DiMaggio's theory of mimetic and normative isomorphism, which contends that the more success organizations have in the field, the more frequent replication will occur. Business schools replicated each other, creating hundreds of bachelors of business programs, and over 600 MBA programs by the 1980s (Khurana, 1997). Khurana describes the trajectory as follows:

In 1972, about 32,000 MBA students graduated from around 400 MBA programs-nearly twice as many such programs as had existed in 1964, when the Ford Foundation terminated its business-education project. By 1980, more than 57,000 MBA students were graduating from more than 600 U.S MBA programs, accounting for one in five of the total number of master's degrees granted. p. 292

But as long as the market was content with the minimum requirement of a business degree, there was no need to improve the standards. This was evident in Hugstad's study in 1983. His research was conducted approximately two decades after the AACSB mandated the inclusion of the liberal arts in the business curriculum. By this time business schools have made the AACSB changes needed to their programs and many graduates from these programs have been working in the field. Hugstad's purpose of the study was to verify whether the industry 
still preferred the practical training over the analytical and theoretical approach and whether there was a convergence of attitudes between academicians and industry executives on various topics. He surveyed 125 personnel directors, 250 deans of liberal arts schools and 125 deans of business schools. His findings in one particular area of the study showed that business personnel directors in the industry were indifferent to the inclusion of the liberal arts in business programs, while prioritizing career preparation as a central part of students' training of business students at the college level. As long as the graduates were able to meet the day-to-day demands of the job, no additional training was demanded by the industry.

\section{Institutional Factors}

Other factors facing business education related to the institutions, faculty, and administrators within it. As previously indicated, the proliferation of business institutions persisted from the 1980 s to the 21 st century. This created a resource problem to institutions in terms of business faculty. The AACSB reported a shortage of business faculty, especially at the doctoral level (Baron-Nixon, 2007; Olian et al., 2002; Pearce, 1999). In certain business disciplines such as accounting, over half the faculty in business institutions were professionally qualified rather than academically qualified, judging by the lack doctoral degrees in their training. Additionally, business faculty had significant pressure placed upon them due to the dynamic environment in business in terms of technology and globalization (Crainer \& Dearlove, 1999; Olian et al., 2002; Porter \& McKibbon, 1988) which required them to continuously gain new expertise. This group of faculty that is deficient in advanced theoretical training surely influenced the training of business students. In 1950, an internal memorandum of Ford Foundation assessment report, quoted in Khurana (2007), described the quality of business faculty in that era, as follows:

The quality of business education is generally inferior, a fact admitted by many responsible individuals in the field of business education. Indeed, to put the matter in its harshest light...the problem consists of unimaginative, nontheoretical faculties teaching from descriptive, practice-oriented texts to classes of second-rate vocationally-minded student. (p. 249).

As of 2004, this legacy in the origination of business education has continued to impact the discipline today. The percentage of part-time faculty and professional faculty continued to exceed 51 percent of total faculty, and only 11 percent of part-time faculty held doctoral degrees (Cataldi, Bradburn, Fahimi, \& Zimbler, 2004). This teaching workforce that lacked the training in research may have impacted business students' ability and desire to pursue doctoral education in business. This shortage of qualified faculty was exacerbated by the weak financial situation that many educational institutions face, which forced them into hiring less expensive faculty. Colleges and universities, due to the decrease of government funding, had to balance out the need of hiring qualified faculty with the need to reduce their costs. Moreover, the AACSB exacerbated this trend of hiring professional, and part-time faculty rather than academic faculty, and in 2003 accreditation revision, the AACSB loosened their criteria for minimum percentages of academic faculty needed at institutions to maintain accreditation (Miles, Hazeldine, \& Munilla, 2004). The AACSB was not asking for higher percentages of academic faculties in the ranks, nor was the industry. The resource dependency between industry and academia (Powell \& DiMaggio, 1997) further created unintended consequences suboptimal to the missions of the schools. Business enterprises cared more about the production of business graduates due to the burgeoning need, more than the high caliber of qualified faculty, high academic standards for graduates, or their professional training. These circumstances explain much of the status quo in business education today.

Another large influence on academic institutions is the main accrediting agency for business programs in the United States, the AACSB. This accrediting agency has been accused of not attempting to enforce professional and ethical curriculum within business education (Mulligan, 1987; Swanson \& Frederick, 2003). After the recent unprecedented number of corporate financial scandals, the AACSB remained inexplicably silent in response to the crisis. Moreover, in the recent massive changes to the accreditation standards in 2003, the AACSB did not specify how business schools will integrate professional and ethical training for business students. Instead, the AACSB allowed business programs to decide on how to incorporate ethical curriculum within their courses, and no single course of ethics was required for accreditation (Swanson \& Fisher, 2009; Swanson \& Frederick, 2003). Therefore, any coverage of professional content will be superficial and inconsistent, and any effort from business schools' faculty to weave new content into the various courses such as marketing, finance, accounting and strategic 
management, will certainly be of lesser priority than the content in the subject matter (Swanson \& Fisher, 2009).

All of the aforementioned influences have shaped the course offerings of business schools, the quality of instruction, and more importantly the learning outcomes of business graduates.

\section{Economic Influences}

Funding at public business schools is largely supported by government, in addition to tuition dollars. Private business schools rely primarily on program fees, and funding from high profit-margin, specialized programs such as executive education (Gregg \& Stoner, 2008; Hawawini, 2005). Notably, up to 40 percent of US business schools' operating budgets is covered by donations from alumni and to a lesser extent support from corporate sector (Hawawini, 2005). This multi-tier funding structure with a significant percentage of the operating budget derived from the private sector fortifies the ties between industry and academia, and further embellishes the influences of the "Resource Dependency" theory explained above. This reliance on industry almost guarantees that no business school's offering will change without the private sector's demands, and no priorities will be added without the consent of the market and its players.

Another force influencing business education is the competition over tuition dollars for programs. With the growing demand on business education, schools had to vary their offerings to students. Many programs emerged with supplemental online, part-time, and evening programs to meet student demand. Supplementation occurred not just in undergraduate level but also in graduate or MBA programs. Part-time MBA programs exceeded full time programs in 2000 according to a study by the AACSB. These non-traditional programs constituted 58\% of all programs at AACSB accredited schools (Olian et al., 2002). Traditional programs are facing formidable difficulties competing with such new offerings. Many of the new programs have a non-traditional faculty force that does not use the tenure system. These non-traditional programs have a stronger market emphasis offering business needed skills rather than theoretical pedagogy. The availability of the non-traditional programs forces the traditional programs to lose tuition dollars from students selecting these programs, in order to match themselves with the needs of industry (Pearce, 1993). Another facet to flexible and distance business learning is the non-standardization of business curriculum leading to different skill-sets for students. For example, how does a business graduate from the University of Phoenix compare to a business graduate from University of California, Riverside? Gauged perception of professional fortitude presents another challenge to standardize the quality and content of all the programs offered (Olian et al., 2002). Although the AACSB identified this area as a risk for the profession, their analysis has not yet addressed the ways to assess the quality of these non-traditional programs.

One other economic influences on academic institutions is the present ranking system of schools that has been created by the media - e.g. those in magazines such as Forbes, and online business schools. These ranking systems place the highest emphasis on the hiring salaries of recent graduates rather than the quality of the program. The assumption is if the market is paying a higher salary for a graduate from Northwestern rather than Stanford University then the quality of the Northwestern program must be superior. In the meantime many other factors are ignored such as the competence of faculty, research quality, and training of graduate students. These external signs of success or failure have replaced the internal markers for quality that may help outsiders assess how business programs measure against the higher aims of the profession rather than the monetary rewards(Khurana, 2007).

As can be seen, the market and the mechanism of capitalism within it has been the driving force behind business education (Slaughter \& Rhoades, 2004; Starkey \& Tiratsoo, 2007). In this case, the essential determinant for business school quality was the starting salaries of graduates, which heavily depended on the branding and the marketing of programs-- another phenomenon of academic capitalism (Pearce, 1999). In order to improve the quality of business schools to benefit society at large, the ranking system has to focus on programs strengths in areas such as research and instruction quality, content of the program offerings, and the ethical and professional training of the business manager (Khurana, 2007; Starkey \& Tiratsoo, 2007; Wilbur, 1984). 


\section{CONCLUSION}

Business educational institutions bear a central mission in the training of business managers (Pfeffer \& Fong, 2004; Porter \& McKibbon, 1988). In spite of the advancements that business schools have made in the century of their existence, much is left in improving and understanding the outcomes of training of business managers, as expressed by Khurana (1997): "From the historical perspective, business schools have evolved over the century and a quarter of their existence into their own intellectual and institutional antithesis, in a process of development that is, as yet, little understood and generating consequences that we are only now beginning to comprehend and reckon with" p. 4 The harder that business schools attempt to weave ethical content within their programs the further away their graduates and their outcomes seem to match these efforts (Swanson \& Frederick, 2001).

Understanding the historical influences on business education helps explain the original intent of establishing the discipline at the university level and making it worthy of students' pursuit of higher education. The original mission was to treat business as a "profession" where the highest professional standards can be taught to managers, in order for managers to become ethical and responsible agents to shareholders and society. However, the history is clear; colleges and universities took advantage of the burgeoning demand on business education to support their institutional budgets and relegated this original mission (Khurana, 2007; Krause, 1999). Academic institutions getting caught in the practice of "academic capitalism" became market and bottom-line driven and lost sight of their social responsibility to the profession and to society. Perhaps the re-education of the current guards of business institutions is due as the day-to-day management of business schools makes many of them forget the original intent of having the business discipline in higher education.

The ideological influences must be reconciled. The "profit-maximization" responsibility to shareholders and the "social responsibility" of business managers to society are dual duties that every manager needs to understand and be trained to handle and prioritize. Business schools' curriculum and instruction are lacking when it comes to professional training of managers (Khurana, 2007; Mintzberg, 2004; Swanson \& Fisher, 2008). Many calls to integrating soft-skills such as "multi-cultural awareness," "societal values," and "ethical and professional skills" have been side-stepped and pushed aside in favor of expert or quantitative topics in the fields of marketing, finance, accounting and management (Mintzberg, 2004). The main accreditation agencies, such as the AACSB, have long ignored the necessity for professional and ethical trainings where business students can be assessed in their knowledge prior to handing them the degree and the license to become business managers and agents of societal wealth (Khurana, 2007; Swanson \& Fisher, 2008, 2009; Swanson \& Frederick, 2001). And imagine this, if each business student intending to be a director or a vice-president of a company had to obtain professional training and a license before they are handed the keys to their office, how different business students' attitudes would be toward societal responsibility.

Another ideological conflict in business schools' training is the industry's demand on "expert skills" rather than "professional expertise." As long as the industry is not paying higher wages and creating positions demanding the professional skills, business schools will not shift their curriculum; why train students on skills that have no market value? This is where the regulatory and accreditation agencies come to play. If business schools are complicit with the industry's demands on skills that do not serve society, then regulatory forces must step in and require what the marketplace fails to demand - business managers that are trained as professionals and not as hiredagents serving a select tier of influential shareholders.

Institutional and economic challenges play hand-in-hand. Economic influences and financial pressures that business schools face force them to take short-cuts, use less-trained faculty, and customize their offerings to the highest profit margins. If accreditation agencies are not requiring better qualified faculty, enhanced professional knowledge of students, then why would business schools presidents and deans force it on their institutions. Therefore, the AACSB has to reexamine its mission and reevaluate its professional agenda, before it loses its value to the profession (Noland \& Sinclair, 2008; Swanson \& Fisher, 2009; Swanson \& Frederick, 2001).

This paper has presented perspectives from management science, education, and economics that may comprise a useful conceptual framework for understanding the problems at hand. While some analytical discussions 
presented addressed some of the questions surrounding the current status of business education and the trajectory that it should take, alternative approaches are needed to offer more comprehensive solutions.

\section{AUTHOR INFORMATION}

Lana S. Nino is an Associate Professor in Business Administration at Whittier College. Her current research interests are in the area of business education and the international accounting standards where she has published several articles. Lana started her career in public accounting at Arthur Andersen \& Co. and spent six years in public accounting in both audit and tax practices. She held the Chief Financial Officer position for two technology companies in California prior to joining academia. Lana is a Certified Public Accountant (CPA) and a Certified Information Systems Auditor (CISA). She has an MBA from California State Polytechnic University, Pomona, and an Advanced Executive Certification from the Kellogg School of Business at Northwestern.

\section{REFERENCES}

1. Abbott, A. (1988). The system of professions: An essay on the division of expert labor: University of Chicago Press Chicago.

2. Baron-Nixon, L. (2007). Connecting Non Full-time Faculty to Institutional Mission: A Guidebook for College/University Administrators and Faculty Developers. Stylus Publishing, LLC, 224.

3. Behrman, J., \& Levin, R. (1984). Are business schools doing their job. Harvard Business Review, 62(1), 140-147.

4. Benson, P. (2004). The Evolution of Business Education in the US. Decision Line, 35(2), 17-20.

5. Brint, S. (1996). In an age of experts: The changing role of professionals in politics and public life: Princeton Univ

6. Cataldi, E., Bradburn, E., Fahimi, M., \& Zimbler, L. (2004). National Study of Postsecondary Faculty (NSOPF: 04): Background characteristics, work activities, and compensation of instructional faculty and staff: Fall 2003 (NCES 2006-176). US Department of Education, Washington, DC: National Center for Education Statistics. Retrieved February, 6, 2006.

7. Crainer, S., \& Dearlove, D. (1999). Gravy training: Inside the business of business schools: Jossey-Bass San Francisco.

8. Cruikshank, J. (1987). A delicate experiment: the Harvard Business School, 1908-1945: Harvard Business Press.

9. Daniel, C. (1998). MBA: The first century: Bucknell Univ Pr.

10. Drucker, P. (1968). The Graduate Business School. Fortune, 42(August), 92-94.

11. Epstein, D. (2006). Rethinking the MBA Curriculum. Inside Higher Education.

12. French, R., \& Grey, C. (1996). Rethinking management education: Sage Publications Ltd.

13. Friga, P., Bettis, R., \& Sullivan, R. (2003). Changes in graduate management education and new business school strategies for the 21st century. Academy of Management Learning and Education, 2(3), 233-249.

14. Gordon, R., \& Howell, J. (1959). Higher education for business: Garland New York.

15. Gregg, S., \& Stoner, J. (2008). Rethinking Business Management: Examining the Foundations of Business Education. Princeton, New Jersey: Witherspoon Institute.

16. Hawawini, G. (2005). The future of business schools. Journal of Management Development, 24(9), 770782.

17. Hugstad, P. (1983). The business school in the 1980s: Praeger, New York, NY.

18. Khurana, R. (2007). From higher aims to hired hands: The social transformation of American business schools and the unfulfilled promise of management as a profession: Princeton Univ Pr.

19. Krause, E. (1999). Death of the Guilds: Professions, States, and the Advance of Capitalism, 1930 to the Present: Yale Univ Pr.

20. Mårtensson, P., Bild, M., \& Nilsson, K. (2008). Teaching and learning at business schools: Transforming business education: Gower Publishing Company.

21. Miles, M., Hazeldine, M., \& Munilla, L. (2004). The 2003 AACSB accreditation standards and implications for business faculty: A short note. The Journal of Education for Business, 80(1), 29-34.

22. Mintzberg, H. (2004). Managers not MBAS: Berrett-Koehler New York.

23. Mulligan, T. (1987). The two cultures in business education. Academy of Management Review, 593-599. 
24. Noland, T., \& Sinclair, D. (2008). AACSB Accreditation: Symbol Of Excellence Or March Toward Mediocrity? Journal of College Teaching \& Learning, 5(5).

25. Olian, J., Caldwell, L., Frank, H., Griffin, A., Liverpool, P., \& Thomas, H. (2002). Management Education at Risk: A Report from the Management Education Task Force: The Association to Advance Collegiate Schools of Business (AACSB) International. Available online at: http://www.aacsb.edu/Publications/metf/default.

26. Pearce, J. (1999). "Faculty survey on business education reform.". The Academy of Management Executive, $13(2), 105$.

27. Pfeffer, J., \& Fong, C. (2004). The Business School'Business': Some Lessons from the US Experience*. Journal of Management Studies, 41(8), 1501-1520.

28. Pfeffer, J., \& Salancik, G. (2003). The external control of organizations: A resource dependence perspective: Stanford University Press.

29. Pierson, F. (1959). The education of American businessmen. New York.

30. Porter, L., \& McKibbon, L. (1988). Business education and development: drift or thrust into the 21 st century: New York: McGraw-Hill.

31. Slaughter, S., \& Rhoades, G. (2004). Academic capitalism and the new economy: Markets, state, and higher education: Johns Hopkins Univ Pr.

32. Starkey, K., \& Tiratsoo, N. (2007). The business school and the bottom line: Cambridge Univ Pr.

33. Swanson, D., \& Fisher, D. (2008). Business Ethics Education. Advancing Business Ethics Education, 1.

34. Swanson, D., \& Fisher, D. (2009). Business Ethics Education: If We Don’t Know Where We're Going, Any Road Will Take Us There. Decision Line, 11.

35. Swanson, D., \& Frederick, W. (2001). Campaign AACSB: Are business schools complicit in corporate corruption? Journal of Individual Employment Rights, 10(2), 151-165.

36. Swanson, D., \& Frederick, W. (2003). Are business schools silent partners in corporate crime? Corporate Citizenship, 24.

37. Wilbur, J. (1984). The Integration of Ethics Into Business Education: Essays on the SUNY College at Geneseo Experience: State University of New York. 
NOTES 